\title{
$-5-$ \\ Hebrew, Hieroglyphs, and the Secrets of Divine Wisdom in Ludovico Mazzolino's Devotional Paintings
}

\author{
Giancarlo Fiorenza
}

S

ecrecy operated on many levels within Renaissance court society. At Ferrara, the mechanisms of secrecy helped shape and define the rule of Alfonso I d'Este (1476-1534; duke from 1505). His biographer, Paolo Giovio, observed that the duke frequently retreated to a secret room ("stanza secreta") in the Ferrarese castle, which was set up like a workshop ("bottega"), in order to create a variety of decorative and sculpted objects, activities he performed to relax his spirit and escape idleness ("per fuggire l'otio"). ${ }^{1}$ Within these private chambers-rooms not so much hidden as separated from the common areas and reserved for the duke-Alfonso combined solitude with industry, and leisure with sprezzatura, leaving his subjects to marvel at the virtuosity fueling princely performance. ${ }^{2}$ Visitors granted access to these spaces bore witness to the practice of seclusion as an agent of production and authority, an ideology that informs other works of art celebrating the duke: from the inscriptions invoking quies and solus on Antonio Lombardo's marble reliefs (ca. 1508), once displayed in the private suite of rooms in the ducal residence known as the camerini d'alabastro (possibly near the stanza secreta mentioned above), ${ }^{3}$ to Mercury's gesture of silence in Dosso Dossi's Jupiter Painting Butterflies (ca. 1524; National Art Collection, Wawel Royal Castle, Karków) (fig. 5.1), executed most likely for the Villa Belvedere, a

1. Giovio, Liber de vita, 7; Italian translation by Gelli, La Vita di Alfonso da Este, 15-16. Giovio's observation is corroborated by a letter dated 26 November 1523, in which the duke writes to his sister Isabella d'Este of Mantua, stating that he was sending her a gift of ceramic dishes that he had made and decorated in his secret spaces ("nostri loghi secreti"); see Magnani, La ceramica ferrarese, 1:15.

2. For a study of these "secret" rooms and studioli, see Folin, "Studioli, vie coperte, gallerie," 97-109; and Liebenwein, Studiolo. Campbell, Cosmè Tura, 29, observes, "The symbolic force of the private study in figuring the 'contemplative life' was not itself new; what distinguished the princely studio was its redirection of humanist ideals of privacy (otium) towards the political ends of display.... In essence the studio was a backdrop against which the prince could stage the appearance of industrious solitude, thereby affirming the humanist ideology of personal culture as an entitlement to rule."

3. For Lombardo's reliefs and their inscriptions, see the entries in the exhibition catalogue Il Camerino di alabastro: Sheard, "Antonio Lombardo's Reliefs," and Goodgal, “Camerino of Alfonso I d'Este." The precise location of the camerini d'alabastro in the Via Coperta, a narrow stretch of residential quarters connecting the ducal castle to the palace quarters, remains unresolved. Certain rooms in the Via Coperta display Alfonso's name (ALFONSVS.DVX.III) carved on the architrave of the marble door frames, such as the one leading into the Camera del Poggiolo; see Borella, "Lo 'Studio de preda Marmora fina,"' 117; and Hope, "I Camerini d'alabastro." 


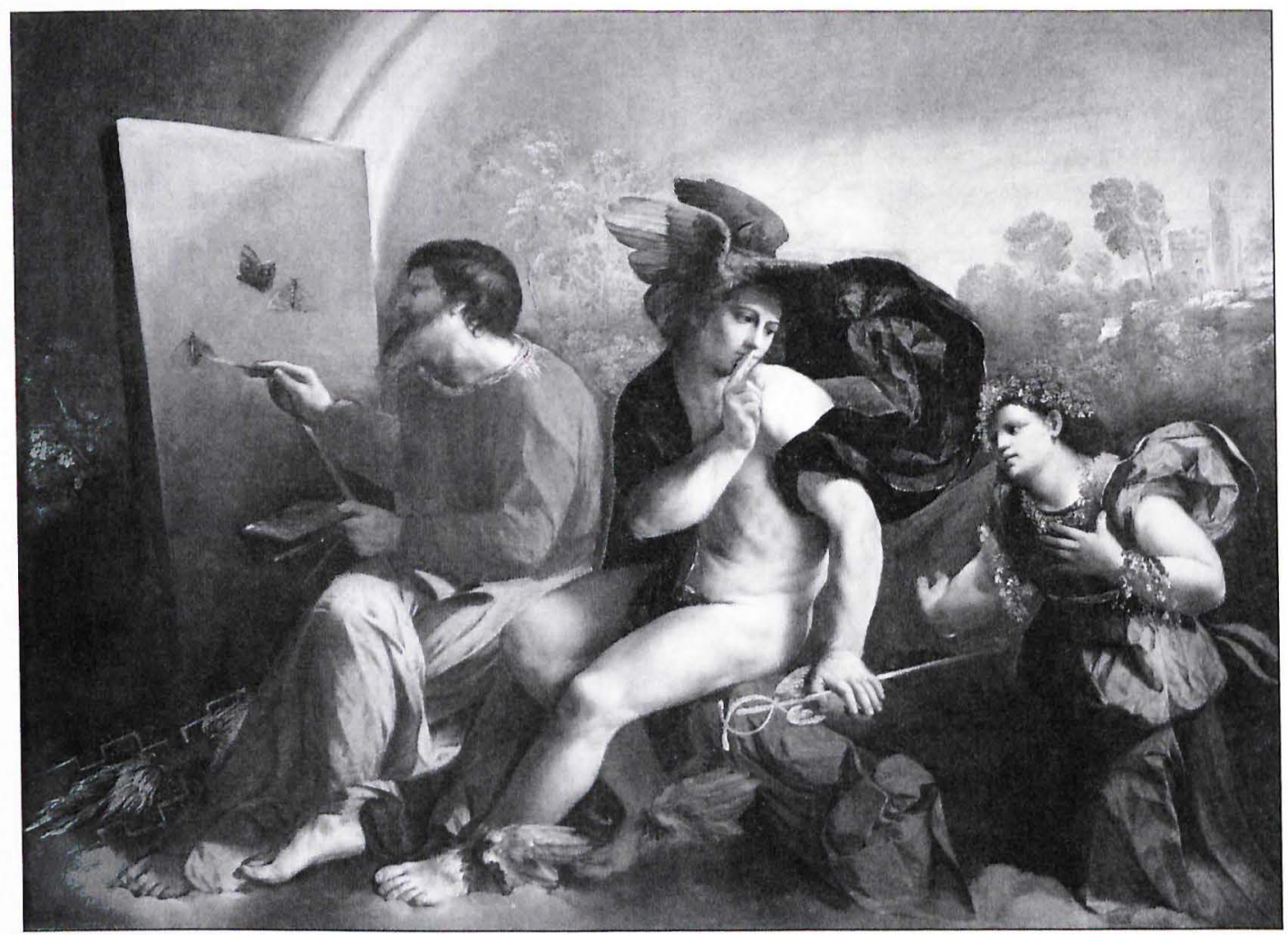

FIGURE 5.1. Dosso Dossi, Jupiter Painting Butterflies, ca. 1524, oil on canvas, Kraków National Art Collection, Wawel Royal Castle.

Erich Lessing / Art Resource, NY.

private estate situated just outside the walls of the city and in the middle of the river Po. ${ }^{4}$ In Dosso's painting, Jupiter figures as an idealized image of a ruler, one who mandates privacy and silence so as not to be distracted from his tranquil but nonetheless official duties of ordering nature, a metaphor frequently aligned by Ferrarese humanists with prudent statecraft. ${ }^{5}$

Alfonso sponsored a court culture heavily invested in secrecy, dissimulation, silence, and visual and verbal ciphers, thereby perpetuating the recurring theme within Renaissance humanist thought that "noble matters" are the possession of the elite. ${ }^{6}$ Celio Calcagnini (1479-1541), who served as apostolic protonotary, Este court historian, and chair of the Faculty of Rhetoric at the University of Ferrara, appreciated the paradoxical nature of secrets. He argued in various letters and treatises that mysteries, whether verbal or visual, pagan or divine, are like treasures, being

4. For an interpretation of Dosso's Jupiter Painting Butterflies, especially in relation to Lombardo's reliefs, see Fiorenza, Dosso Dossi, 21-77.

5. Fiorenza, Dosso Dossi, 56-63.

6. See, more broadly, Snyder, Dissimulation and the Culture of Secrecy, who also discusses such practices at Ferrara (51). 
valuable only when prudently unearthed, and not buried forever: "Mysteries are always mysteries, so long as they are not conveyed to profane ears."

Secrecy was not exclusively elitist, but also very practical for Este rule. By advocating solitude and silence in the making and meaning of works of art, Alfonso demonstrated his understanding of the dual nature of secrecy: that it implies its own revelation and structures identity and subjectivity through a body of knowledge. As Karma Lochrie explains, secrecy is never as solitary an activity as it purports to be. ${ }^{8}$ Instead, secrecy operates in distinct social contexts, configuring power relations, with reticence, prudence, and the dissimulation of effort in brilliant production lending the Este duke a special veneer to his identity. It is from the complementary perspectives of dissimulation and disclosure, of revelation and performance of what has been mystified that this essay will investigate specific examples of Este artistic patronage, specifically small-scale, personal devotional paintings, and how they served not only as instruments of piety for a Christian prince, but moreover, as exoteric rhetorical devices. ${ }^{9}$

In the year 1527, the Ferrarese artist Ludovico Mazzolino (ca. 1480-after 1528) painted two works for the duke: Christ Washing the Apostles' Feet (Philadelphia Museum of Art) (fig. 5.2) and Christ and the Money Changers (Alnwick Castle, Northumberland). ${ }^{10}$ While not strictly pendants owing to their different sizes, these two works present Christ as an exemplar of humility and as an enforcer of justice, kneeling modestly before his disciples in one panel and driving the defilers out of the temple of Jerusalem in the other. Christ's deeds and actions constitute models of imitation for Alfonso, who needed to rule his subjects benignly but with uncompromised authority. The scene of the sacrifice of Isaac in the architectural roundel of the Philadelphia panel reinforces the theme of obedience, from the unquestioning compliance to God's command to gestures of communal respect and service among Christ and his apostles.

In the Renaissance, Christ's words were valued for their veiled wisdom. For Erasmus of Rotterdam, Christ appears as a great teacher, with scripture as the book containing hidden spiritual meaning. ${ }^{11}$ He explains in his adage Sileni Alcibiades (1515) that the intentional obscurity of the biblical parables and the veils of figurative language employed by Christ exercised one's cognitive skills: "The parables of the Gospel, if you take them at face value-who would not think that they came from a simple ignorant man? And yet if you crack the nut, you find inside that profound wisdom, truly divine, a touch of something which is clearly like Christ himself." ${ }^{2}$ Christ's deeds and sayings were not only moral but at the same time practical and adaptable to personal and political contexts, witnessed, for example, by Christ's statement of unity, "The servant is not greater than his lord" (John 13:16; KJV), spoken to his apostles after he washed their feet.

7. Calcagnini, Opera aliquot, 27, cited and translated in Wind, Pagan Mysteries in the Renaissance, 11. On Calcagnini's career, see Tiraboschi, Storia della letturatura italiana, 7.3:870-73; Piana, Ricerche ed osservazioni; and Lazzari, "Un enciclopedico del sec. XVI."

8. Lochrie, Covert Operations, 1-4. See also Eamon, Science and the Secrets of Nature.

9. On the importance of "small forms" for Renaissance rhetoric, see Colie, Resources of Kind, esp. 32-75.

10. See Zamboni, Ludovico Mazzolino, 26-27, 50n51 (Christ Washing the Apostles' Feet), and 25-26, 35n I (Christ and the Money Changers); and Ballarin, Dosso Dossi, 1:257 (Christ Washing the Apostles' Feet); 259--60 (Christ and the Money Changers). I agree with Zamboni (33) with regard to the patronage of these two panels and the corresponding documents cited.

11. See O'Malley, "Content and Rhetorical Forms," 243-44, for Erasmus's view of Christ as a great teacher and scripture as the book containing his "philosophy."

12. Mann Phillips, "Adages" of Erasmus, 276. Erasmus goes on to say that "when it is a matter of knowledge, the real truth always lies deeply hidden, not to be understood easily or by many people." 


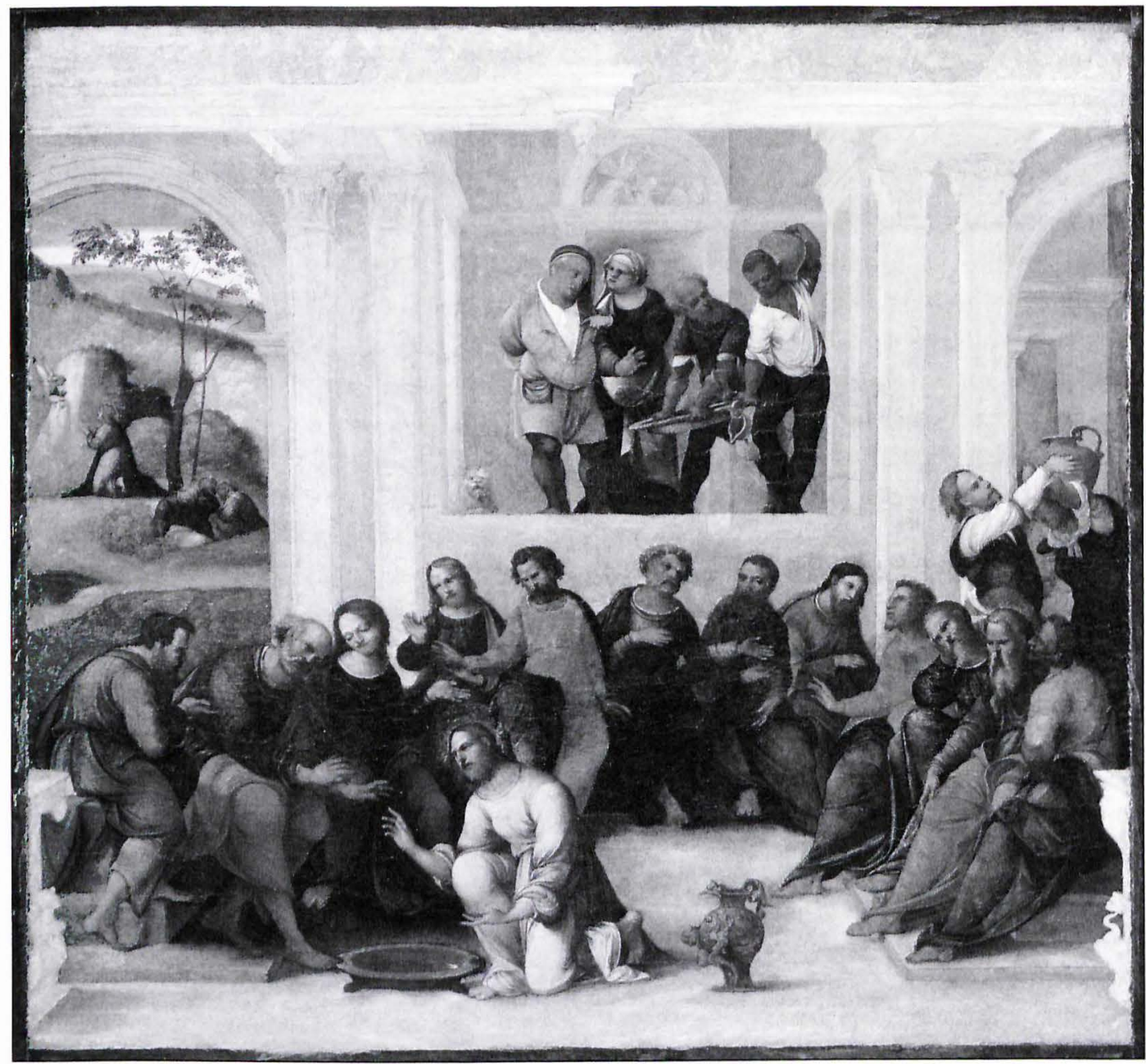

FIGURE 5.2. Ludovico Mazzolino, Christ Washing the Apostles' Feet, 1527, oil on wood, Philadelphia, Philadelphia Museum of Art.

The Philadelphia Museum of Art / Art Resource, NY.

Mazzolino's images coincide with the development of a humanist theology in sixteenth-century Italy, or what John O'Malley and Salvatore Camporeale, among others, define as sacred oratory infused with classical rhetorical precepts, whereby the art of praise and blame concerning the events of Christ's life and his teachings (his beneficial ministry) overshadowed the focus on abstract doctrines and dogma in preachers' sermons. ${ }^{13}$ The image of Christ in the duke's pictures is one of an exemplary individual who combines wisdom, eloquence, and action to affect the moral fabric of society. Through his artistic patronage Alfonso publicized his piety while structuring his role as a caretaker and distributor of divine wisdom in the service of effective leadership. 
Mazzolino specialized in small-scale paintings emphasizing Christ's ministry, exemplified by his frequent renditions of Christ's disputations. Certain works depict episodes of Christ's teachings within elaborate portrayals of Solomon's temple at Jerusalem, ornamented with hieroglyphic and Hebrew inscriptions, two ancient languages that were valued in the Renaissance for their ability to simultaneously conceal and reveal the secrets of divine wisdom. ${ }^{14}$ The various forms of ancient and arcane media in Mazzolino's paintings did not merely target, but more readily helped produce, shape, and maintain an exclusive audience, one able to decipher, deliberate on, and judiciously explicate and apply the sacred mysteries of Christ's teachings that are (at least notionally) safeguarded by hieroglyphic and Hebraic veils. My emphasis will be on the humanistic nature of Mazzolino's imagery: how he shows Christ as subsuming, supplanting, and ultimately translating into the sphere of action the secrets of divine wisdom embodied in the ancient paraphernalia. Not only did Christ's teachings and his miracles prove his divinity and fulfill God's covenant, but they also established a testimony to authority - an ultimate referent for the unveiling of sacred enigmas-for Christian princes and their courtiers.

Mazzolino worked extensively for the Este family, from decorating the private apartments of Duchess Lucrezia Borgia to executing small-scale, personal devotional paintings for Alfonso and his brothers Ippolito and Sigismondo. ${ }^{15}$ Relatively few documents survive that can be securely connected to his existing works. Nevertheless, there was a long tradition in Ferrara of artists collaborating with the Este and their humanist advisers. ${ }^{16}$ While not all of the images discussed below have a clearly documented Este provenance, Mazzolino's use of Hebrew and hieroglyphs helped construct a reconciliatory, catholic knowledge regarding divine wisdom for his courtly audience. This form of participatory yet privileged viewing experience facilitated the diplomacy operating within the Ferrarese court in the early sixteenth century, especially in light of the city's well established and growing Jewish community - a community tolerated and protected by the Este, often in the face of opposition. Mazzolino's work for the Ferrarese court also received attention by elite patrons in nearby Bologna, resulting in paintings equally layered with meaning and containing hidden treasures of divine wisdom.

The early provenance of Mazzolino's Christ Disputing with the Doctors (fig. 5.3), completed around 1522, and now in the National Gallery, London, is undocumented, but the painting serves as a prime example of how the artist structures various media of varying origin and type to celebrate Christ's sacred and secret wisdom. ${ }^{17}$ At the tender age of twelve, during the Passover feast, Christ abandoned his parents and visited the temple of Jerusalem, where he debated with the learned doctors and scribes on undisclosed topics. According to the Gospel of Luke (2:41-51), this was the first occasion on which Christ taught, and the elders were amazed at his understanding

14. See Haitovsky, "Hebrew Inscriptions." See also Busi, Enigma dell'ebraico, 73-97, for Hebrew inscriptions in Ferrarese paintings (including those by Mazzolino) in relation to Ferrarese humanism.

15. On Mazzolino's art and career, see Borsetti, Historiae almi ferrariae gymnasia, 2:451-52; Cittadella, Catalogo istorico de' pittori, 1:96-101; Baruffaldi, Vita di Lodovico Mazzolino; Zamboni, Ludovico Mazzolino; Ballarin, Dosso Dossi, 1:232-61; and the various documents transcribed by Franceschini, Artisti a Ferrara.

16. For specific case studies, see Gundersheimer, "Patronage of Ercole I d'Este"; Schwarzenberg, "Die Lunetten" (Italian translation edited by Bargellesi, "Le lunette"); and Colantuono, "Dies Alcyoniae." On a broader level, see Rosenberg, Este Monuments; Campbell, Cosmè Tura; and Fiorenza, Dosso Dossi.

17. Zamboni, Ludovico Mazzolino, 21, 44-45; Ballarin, Dosso Dossi, 1:250. 


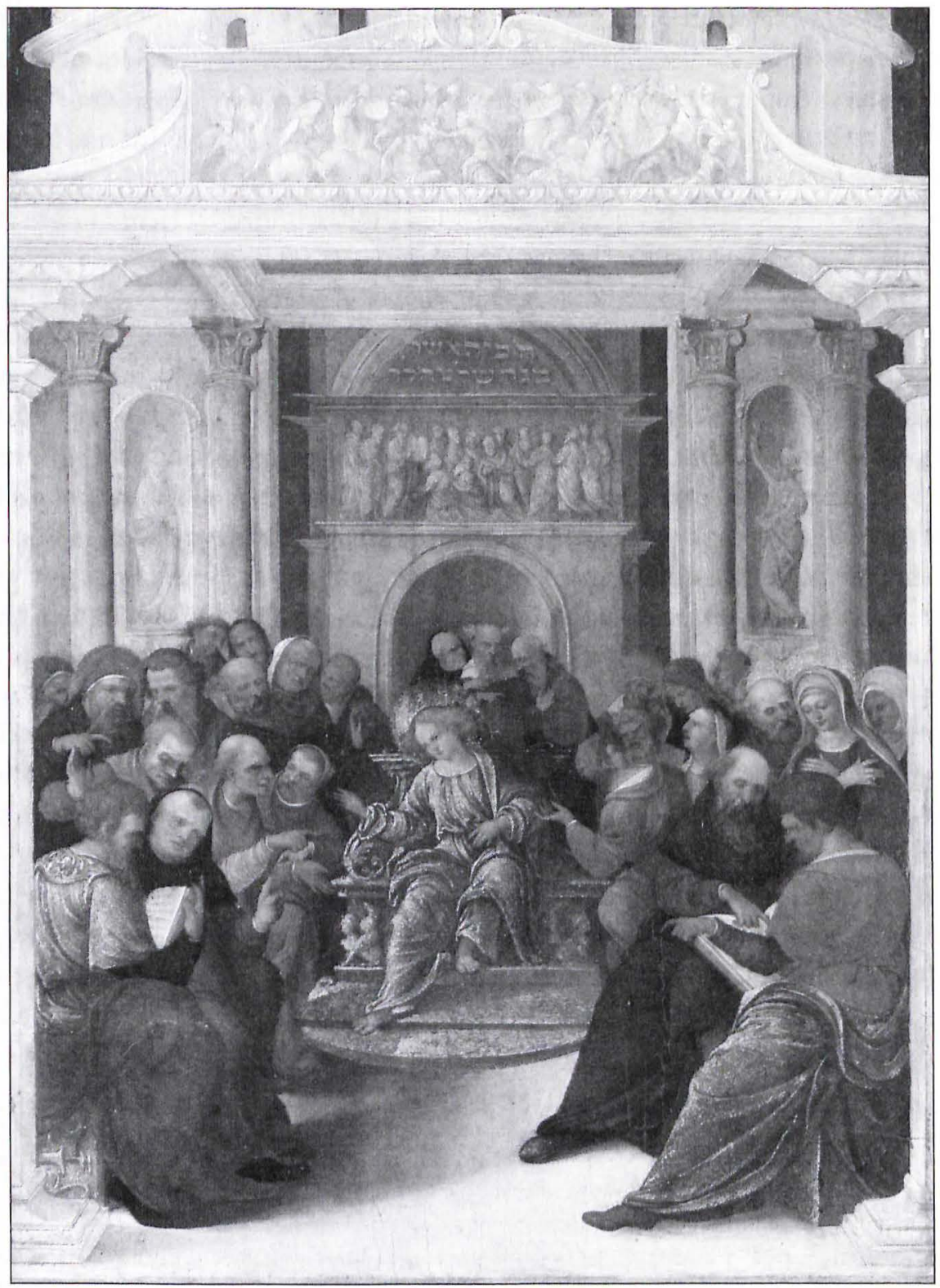

FIGURE 5.3. Ludovico Mazzolino, Christ Disputing with the Doctors, ca. 1522, oil on wood, London, National Gallery.

(C) National Gallery, London / Art Resource, NY. 
of scripture. The Hebrew inscription in the architectural lunette behind Christ reads, "The House which Solomon built for the Lord" (1 Kings 6:2). ${ }^{18}$ This quotation is a conscious anachronism by Mazzolino in an attempt to locate the event within the original temple of Jerusalem, the archetypical house of worship, constructed by Solomon under divine supervision in order to house the ark of the covenant containing the Ten Commandments. Solomon's temple, which was sacked by the Babylonians in $587 \mathrm{BCE}$, was subsequently rebuilt and later expanded by Herod in $20 \mathrm{BCE}$. It was in the so-called Second Temple that Christ held his disputations. Appropriately, Mazzolino depicts Moses giving the Ten Commandments to his people in a monochrome relief just under the inscription, thereby complementing the theme of the preservation and dissemination of God's laws. The first book of Kings equates Solomon with wisdom, namely the wisdom to execute justice within the temple. ${ }^{19}$ As the inventor of parables and spiritual songs, Solomon used his divinely inspired wisdom to preserve and dispense the laws of God. In Mazzolino's composition, Christ appears as Solomon's successor, seated on an elaborate throne with sphinxes at its base, further corroborating the belief that God masked his wisdom. ${ }^{20}$ Whereas the biblical identities of Solomon and Moses are regulated by the written word and monochrome images, Christ springs forth in vivid colors and spirited gestures: he represents the renewal and revelation of divine wisdom that challenges and confounds the Pharisees and their laws. ${ }^{21}$ Mazzolino portrays Christ in the role of a public orator, whose eloquence reaches a broad audience. His verbal performance stands in marked contrast to the ancient battle scenes shown in monochrome relief, visual examples of how the breakdown of rational communication leads to conflict. In essence, the painting seeks to move and delight viewers, promoting the peaceful ministries of Christ, beginning with his first public address, equivalent to the revelation of Mosaic law. ${ }^{22}$

But it would be a mistake to claim that the Hebrew inscription and characters in Mazzolino's London panel produce a set of associations that are exclusively negative or obsolete, merely intended to be overshadowed. On the contrary, by the late fifteenth century, Hebrew was being studied as a philological tool for elucidating scripture. ${ }^{23}$ Although only a handful of Renaissance

18. Translations of the Hebrew inscriptions in Mazzolino's paintings derive from Haitovsky, "Hebrew Inscriptions." The author, 138, observes that the quotation from 1 Kings 6:2 appears in other paintings of the same subject by Mazzolino, as well as in his Ecce Homo (Musée Condé, Chantilly).

19. See especially 1 Kings 3-4.

20. According to Giovanni Pico della Mirandola (1463-94), who adapts a theory originally formulated by Plutarch, the Egyptians adorned their temples with sphinxes "to indicate that divine knowledge, if it is committed to writing at all, must be covered with enigmatic veils and poetic dissimulation"; quoted in Wind, Pagan Mysteries in the Renaissance, 17.

21. See Kessler, "Medieval Art as Argument," for medieval exegeses concerning the pictorial metaphor from the Epistle to Hebrews (10:1), that the law is but a "shadow" to Christ's "true image." Notably, Barrufaldi, Vita di Lodovico Mazzolino, 14n1, observes that Mazzolino painted with "hot and lively" colors, together with interesting portrayals of elders and saints in a manner all his own: "Il colorito di lui è assai caldo e vivace, i suoi vecchi interessanti, e ogni cosa finitissima. Soleva coronare il capo de' suoi santi d'una particular luce a tante aureole concentriche; modo tutto proprio di questo artista."

22. See O'Malley, "Egidio da Viterbo and Renaissance Rome," 80, for the affective dimension of sacred oratory to produce the desired effect of moral betterment.

23. See Resnick, "Lingua dei, lingua hominis"; Friedman, Most Ancient Testimony; and Ruderman, "Italian Renaissance and Jewish Thought." Ruderman observes that while many Christian missionaries and polemicists mined Jewish texts, from rabbinic homilies to the kabbalah, to legitimate the Christian faith and point out the errors, shortcomings, and perversity of Judaism, the intellectual pursuit of Christian humanists, chief among them Marsilio Ficino and Pico della Mirandola, passionately sought to underwrite the essential and catholic divine truths that were common possession of all humanity and all cultures, "a unity and harmony of religious insight, a basic core of universal truth" (397). 
Christians could read Hebrew, there was a strong theological tradition commending Hebrew as a privileged language, original to mankind and preserving the hidden order of nature as designed by God. ${ }^{24}$ One Christian scholar claimed, "For when reading Hebrew I seem to see God Himself speaking when I think that this is the language in which God and the angels have told their minds to man from on high." ${ }^{25}$ Because its script was largely "alien" and illegible, Hebrew was seen to embody a talismanic quality in Renaissance painting. ${ }^{26}$ In this light, the presentation of Christ in debate below the Hebrew inscription in Mazzolino's London Christ Disputing with the Doctors can be seen to offer his patron a more immediate and profound experience with the divine-a dazzling revelation of God's secrets through Christ's oratory.

How might Mazzolino's paintings function at the Este court? Ferrara was an important refuge for Jews expelled or fleeing persecution from other states throughout Europe, and the Este developed close ties with the Jewish community. ${ }^{27}$ On account of its politics of tolerance, the court benefited greatly from Jewish money-lending practices. Under Duke Ercole I d'Este (1431-1505; duke from 1471), Alfonso's father, Ferrara had become an important center for the printing of Hebrew texts. Jews enjoyed exemption from paying taxes by ducal order in 1473, and they established a synagogue in the early 1480s. Ferrarese Christians also took a strong interest in Jewish customs and rituals. In 1498, the Jewish scholar Abraham ben Mordecai Farissol (1452-ca. 1528) performed a ritual circumcision in the Ferrarese house of Pellegrino Prisciani, the astrologer and ducal librarian, who served as a witness in the company of other Christians. ${ }^{28}$ Farissol was highly active in the Italian humanist arena and may have even taught Hebrew to Christians, among them Prisciani, who knew Hebrew well. These events are characteristic of what Jerome Friedman sees as a peculiar trend in the Renaissance of a Judaizing of the Christian religion, of a return to Hebraic sources and practices to determine the meaning of God's words and strengthen the faith. ${ }^{29}$ Farissol, who originated from Avignon and lived for a time in Mantua before settling in Ferrara by 1472, perhaps viewed the religious climate in Italy with a mixture of appreciation and criticism, noting in his Magen Avraham (The Shield of Abraham) of 1500-1512, an anti-Christian treatise, that Judaizing Christians abided by the following:

One of the sages described their faith in the following manner... one should take heed to keep all the practices enjoined ... in the Mosaic law... while remaining faithful to the mystery and prefiguration that is alluded to or ordained in the new teaching of Jesus.... And he believed and affirmed that it was

24. Resnick, "Lingua dei, lingua hominis," S1-74, has assembled a wide range of authorities from St. Jerome to St. Augustine to Dante Alighieri who affirm that Hebrew was the language of Adam, with Hebrew scriptures, because they antedate all other ancient writings, being "more reliable records both of the early history of man and of primordial divine truths" (56). See further Eco, Search for the Perfect Language, 7-33.

25. Quoted in Friedman, Most Ancient Testimony, 73. The quotation is from the German lawyer Johannes Reuchlin (1455-1522), who pioneered the study of Hebrew for Christians, and who argued that "God wished his secrets to be known to man through Hebrew."

26. See Wood, Forgery, Replica, Fiction, 278-79.

27. See above all Ruderman, World of a Renaissance Jew. Also informative are Campbell, Cosmè Tura, 99-129; Franceschini, Presenza ebraica a Ferrara; and Robert Bonfil, "Judeo-Christian Cultural Relations," with further bibliography.

28. On Prisciani, see Rotondo, "Pellegrino Prisciani." Prisciani's connection with Farissol is discussed by Ruderman, World of a Renaissance Jew, 28, and moreover offers a comprehensive biography of Farissol. On Farissol's connection with artists and humanists at the Ferrarese court, see further Busi, Enigma dell ebraico, 73-97.

29. Friedman, Most Ancient Testimony, 182-94 
necessary to be circumscribed and baptized, to wear a prayer shawl and phylacteries and observe all the practical precepts [of the law] and at the same time to remember the Christian concept of God. ${ }^{30}$

Such a convergence between Christian and Jewish cultures continued in Ferrara under the rule of Alfonso I. The duke protected the city's Jewish population, permitting their businesses to prosper and allowing the establishment of a Jewish confraternity, a voluntary pious association known as a Gemilut Hasadim, in $1515 .{ }^{31}$ Ultimately, however, the Este's relationship with the Jews was utilitarian, and the court at times buckled under the pressure of the papacy and other religious institutions. In 1508, for example, Alfonso acquiesced to a combination of thundering sermons, political advice, and public pressure, establishing the Monte di Pietà in Ferrara, which curtailed Jewish money lending. ${ }^{32}$ Tensions between Christians and Jews in Ferrara also manifested themselves in the compulsory theological debates sponsored by the Este.

Sometime between 1487 and 1490, at the request of Duke Ercole I and his wife, Eleanora, Farissol engaged in a series of public debates with Ludovico Valena, a Dominican, and Petrus Malfetta, a Franciscan. ${ }^{33}$ Farissol was also compelled to write down his arguments in order to further defend his answers, all of which he records in his Magen Avraham. The topics of the disputations focused on the legitimacy and relative superiority of Judaism or Christianity, and the participants each deliberated on such issues as prophecy, miracles, divine intervention, Mosaic law, usury, the Incarnation, and the Trinity. Public disputations occurred elsewhere in Italy, at Rimini and Milan, for instance, and while peaceful, they nevertheless served to display the inherent prejudice of the Christian population against the Jews. As has been noted, the spirited tenor of the Ferrarese debates corresponds closely to the liveliness and emotional intensity of Mazzolino's paintings. ${ }^{34}$ Given Farissol's connection with the inner circles of the Este court, in which he cultivated personal friendships with Prisciani and Calcagnini, it is tempting to speculate that he served as an advisor to Mazzolino, spelling out the Hebrew inscriptions in his paintings, and in turn supplying the translation to the artist's patrons. ${ }^{35}$ Whether or not Mazzolino and his courtly patrons actually knew Hebrew is a moot point, because his paintings give the appearance of literacy in the language that God supposedly spoke to Adam. Possession of the painting implies knowledge of its mysterious content. A patron could in turn let the painting "speak" for him without entering into debate, allowing silence to act as a means of dissimulation and circumventing heated encounters. ${ }^{36}$

The use of Jewish imagery and Hebrew inscriptions played both a theological and a political role in Ferrarese art since the fifteenth century. For example, Cosmè Tura's Roverella altarpiece (ca. 1474) and Garofalo's extraordinary fresco of the Crucifix with Ecclesia and Synagoga of 1523, express

30. Friedman, Most Ancient Testimony, 188.

31. Ruderman, "Founding of a Gemilut Hasadim"; Horowitz, "Jewish Confraternal Piety."

32. Ruderman, World of a Renaissance Jew, 85-97.

33. The dispute is analyzed by Ruderman, World of a Renaissance Jew, 57-84.

34. See the observation by Haitovsky, "Hebrew Inscriptions," 141. Haitovsky fails to cite Ruderman's essential study of Farissol and his Magen Avraham, which clarifies the dating of the Ferrarese debates and Farissol's proper life dates.

35. Busi, Enigma dell ebraico, 95-97, notes the connection between Calcagnini and Farissol, and also suggests Farissol as the possible adviser for Mazzolino. As Haitovsky, "Hebrew Inscriptions," 134-35, notes, Mazzolino must have had a Jewish adviser because that name of God is abbreviated in his Hebrew inscriptions, complying with the customs of observant Jews that forbid the spelling out or voicing of God's name.

36. In Calcagnini's dialogue Descriptio silentii, 491-94, he analyzes in detail the practical, rhetorical, and philosophical merits of silence as exemplified by classical authors like Plutarch, Pindar, Xenocrates, and Aesop. 
anti-Jewish ideologies and the politics of toleration respectively. ${ }^{37}$ It follows that there is a political currency to Mazzolino's art as well, one that brokers the Este's relationship with the city's Jewish community. Christ and the Money Changers, noted above, presents a rhetorical enticement in support of the Monte di Pietà established in Ferrara, especially given Farissol's outspoken defense of Jewish money lending. Yet one can also see a more diplomatic and reconciliatory theme operating in Mazzolino's works, which, like Garofalo's fresco, are also cast in antiquity. Ancient customs and writings are brought under the umbrella of Christ's ministry to strengthen Christian leadership.

Further evidence that the Este valued Hebraic learning and ancient Jewish rituals and customs comes from another version of Mazzolino's Christ Disputing with the Doctors, now in the Galleria Doria Pamphilj, Rome (fig. 5.4). ${ }^{38}$ Although Mazzolino painted several versions of this subject, the Doria Pamphilj panel is here identified with the one commissioned by Sigismondo d'Este (14801524), the brother of Alfonso, and paid for on 26 January 1520 . This provenance is based on the dating of the panel on stylistic grounds, the overall high quality of the work in terms of technique and composition, and the complexity of the Hebrew inscription. As in his other works of the same subject, Mazzolino stages an opposition between the Pharisees who, clutching their texts, are bent on enumerating proofs, and Christ, who stands as a model classical orator, stirring his audience and commanding admiration through his speech. ${ }^{39}$ The young Christ rests his arms on a lectern, confident in his debate with the Pharisees, who appear lost in their texts as they attempt a rebuttal. The Hebrew inscription in the architectural roundel contains a unique command from God to Moses and his people, recorded in Leviticus 23:42: "In the sukkah you will dwell seven days every citizen in Israel." ${ }^{40}$ The inscription makes reference to the holiday of Sukkot, or the Feast of Booths. This holiday comes five days after Yom Kippur and commemorates the Jews who fled Egypt and lived in makeshift booths (sukkot) in the desert. Notably, the dedication of the temple of Solomon coincided with the holiday of Sukkot. ${ }^{41}$ As Dalia Haitovsky observes, the inscription aligns the Jewish festival with the consecration of Jerusalem's original temple; subsequently, at the precocious age of twelve, Christ inaugurates his reign of wisdom within that very temple. ${ }^{42}$

Reading the Hebrew permits the patron to make the connection for his audience between the time of the dedication of Solomon's temple and the time of Christ's maturity: the public demonstration of his divine nature and the translation of sacred mysteries through his learning. Sigismondo d'Este's ability to translate and interpret the Hebrew message (even if it was provided

37. On the Roverella Altarpiece, see Campbell, Cosme Tura, 99-129; and Busi, Enigma dell ebraico, 83-90. On Garofalo's fresco, see Katz, Jew in the Art of the Italian Renaissance, 69-98. Following the relaxation of the laws requiring Jews to wear earrings and yellow badges, Hebrew script was one of the most "distinguishing signs" of Jewish identity for Christians; see Owen Hughes, "Distinguishing Signs."

38. Zamboni, Ludovico Mazzolino, 32, 54-55; Ballarin, Dosso Dossi, 1:244.

39. See O'Malley, "Content and Rhetorical Forms," 240 , for the emphasis on movere and delectare in sermons.

40. Haitovsky, "Hebrew Inscriptions," 135-41, also notes the significance of this inscription in relation to Clurist's salvation. The translation in the King James Version reads, "Ye shall dwell in booths seven days; all that are Israelites born shall dwell in booths."

41. On representations of the sukkot in Ferrara, see Manca, "Renaissance Theater and Hebraic Ritual." See further Haitovsky, "Hebrew Inscriptions," 138-39. According to 1 Kings 6:38, the dedication of the temple was postponed for eleven months after its completion. In addition, 1 Kings 8:2 reads, "All the people of Israel assembled to King Solomon at the festival in the month Ethanim, which is the seventh month."

42. The dedication of Solomon's temple thus begins with the Sukkot, and conceptually ends with Ecce Homo, when Christ is presented to the Jews in the temple just before his crucifixion, as noted by Haitovsky, "Hebrew Inscriptions," 138-39. Mazzolino's Ecce Homo, now in Dresden, features the same inscription: "In the sukkah you will dwell seven days every citizen in Israel." 


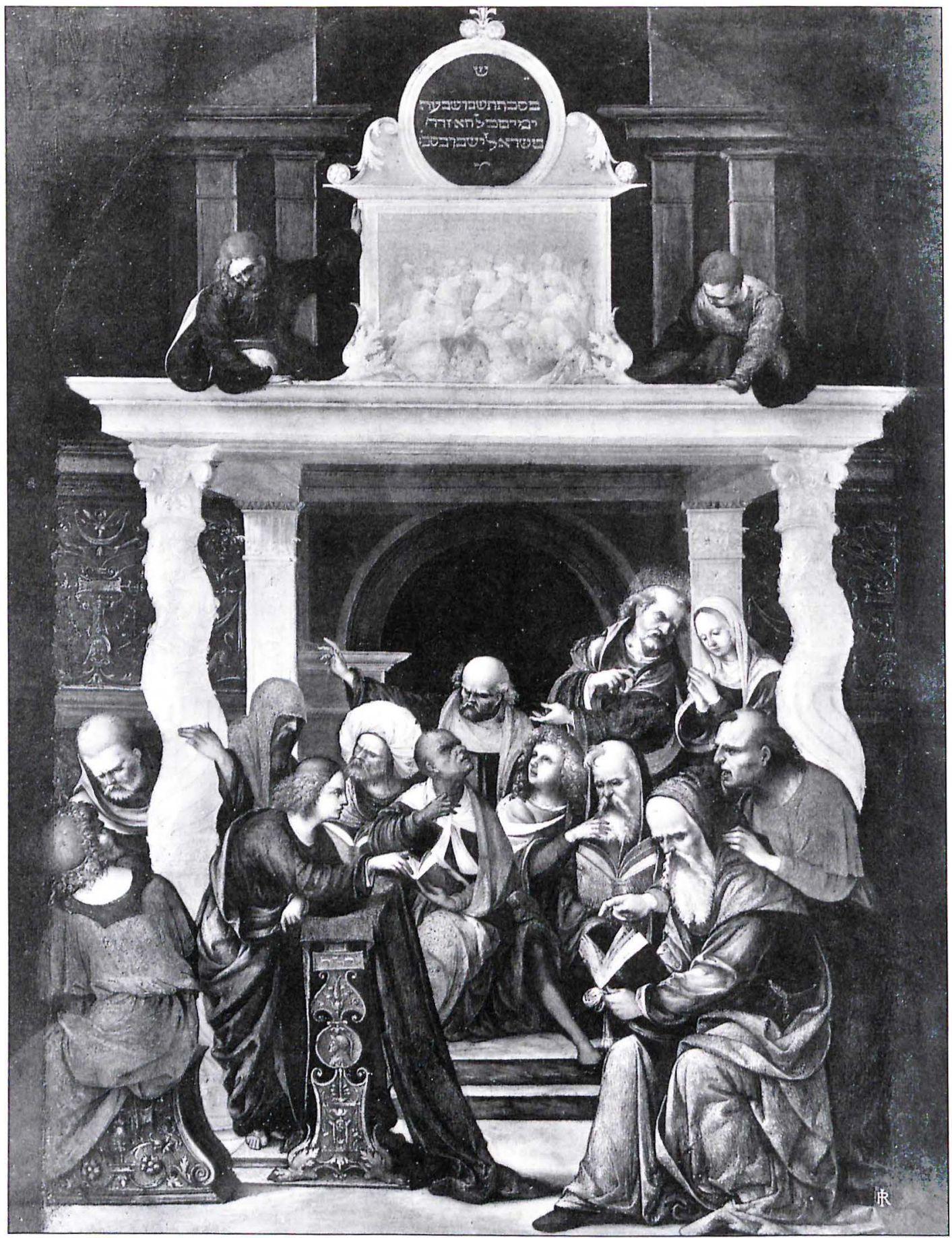

FIGURE 5.4. Ludovico Mazzolino, Christ Disputing with the Doctors, ca. 1520, oil on wood, Rome, Galleria Doria Pamphilj.

Alinari / Art Resource, NY. 
for him) helped shape and affirm his power and superior learning in the face of Ferrara's substantial Jewish community, who might appeal to their own laws and customs as more ancient and therefore more authoritative. Through strategic pairings, Mazzolino's Doria Pamphilj panel merges the sacred laws and festivals of the ancient Hebrews with the public oratory of Christ, who figures as a terminus for divine and benign authority.

Mazzolino's ability to provide his courtly audience with a visual formula that conceals yet reveals sacred wisdom extends to his Christ and the Adulterous Woman, painted around 1519, and now in Florence's Galleria Palatina (fig. 5.5). ${ }^{43}$ This small-scale panel confronts the viewer with the convergence of Hebrew and hieroglyphic inscriptions in the context of Christ's ministry. The original patron is unknown, but the painting expands on the symbolism of the sphinxes found in his London panel mentioned above, implying that Christ provides the doorway to the repositories of ancient mysteries. Although Mazzolino incorporated hieroglyphs in other works, his Christ and the Adulterous Woman is exemplary for staging boundaries of restriction and distinction through a viewing experience.

Numerous Renaissance commentators defined hieroglyphics as a sacred language, seeing the enigmatic ideograms and pictograms used by the ancient Egyptians as encoded with divine truth at the time of God's creation. ${ }^{44} \mathrm{~A}$ well-known example comes from Erasmus in his adage Festina lente (1508), which states that hieroglyphs were used by priests and theologians in Egypt, "who thought it wrong to exhibit the mysteries of wisdom to the vulgar in open writing, as we do; but they expressed what they thought worthy to be known by various symbols, things or animals, so that not everyone could readily interpret them. But if anyone deeply studied the qualities of each object, and the special nature and power of each creature, he would at length... understand the meaning of the riddle." 45 The language of images comprising hieroglyphics represented the language of God, "because God," in the words of the Marsilio Ficino, "has knowledge of things not through a multiplicity of processes, but rather as a simple and firm form of the thing." ${ }^{46}$ As a timeless language, hieroglyphs enabled an immediate and all-encompassing comprehension of the essence (or nature) of the things pictured, combining wisdom and knowledge in the design of images. It should also come as no surprise that hieroglyphs were studied in conjunction with Hebrew in the Renaissance, as both were employed as methods of exegesis, capable of expressing a broad and continually expanding spiritual meaning. ${ }^{47}$

43. Zamboni, Ludovico Mazzoino, 25, 41; Ballarin, Dosso Dossi, 1:245-46.

44. Among the more recent studies on hieroglyphs and Egyptology in the Renaissance are Curran, Egyptian Renaissance; Curran, "Hypnerotomachia Poliphili and Renaissance Egyptology"; Eco, Search for the Perfect Language, 144-77; Wittkower, "Hieroglyphics in the Early Renaissance”; Dempsey, "Renaissance Hieroglyphic Studies"; Galis, "Concealed Wisdom," 363-75; and Iversen, Myth of Egypt.

45. Mann Phillips, "Adages" of Erasmus, 175; and Greene, "Erasmus's Festina lente." In his 1517 translation of Horapollo's Hieroglyphica, the Bolognese humanist Filippo Fasanini also values the symbolic nature of hieroglyphic characters ("hieroglypha grammatica") because of their ability to conceal the most secret doctrines and the most worthy pieces of knowledge of Egyptian religion, yet reveal this information to the learned, who could grasp "the enigma of meaning" ("aenigma sententiae") through informed deliberation, and subsequently obtain the highest honors; see Curran, Egyptian Renaissance, 156-58, 181-82.

46. Quoted in Wittkower, "Hieroglyphics in the Early Renaissance," 116.

47. Dempsey, "Renaissance Hieroglyphic Studies," 345, observes that hieroglyphic was not seen as the exclusive domain of Egyptian culture, but was promoted "as a universal symbolic means of communication among the educated, a means, moreover, inextricably intertwined with speculation about the origins of language and the language of God himself." 


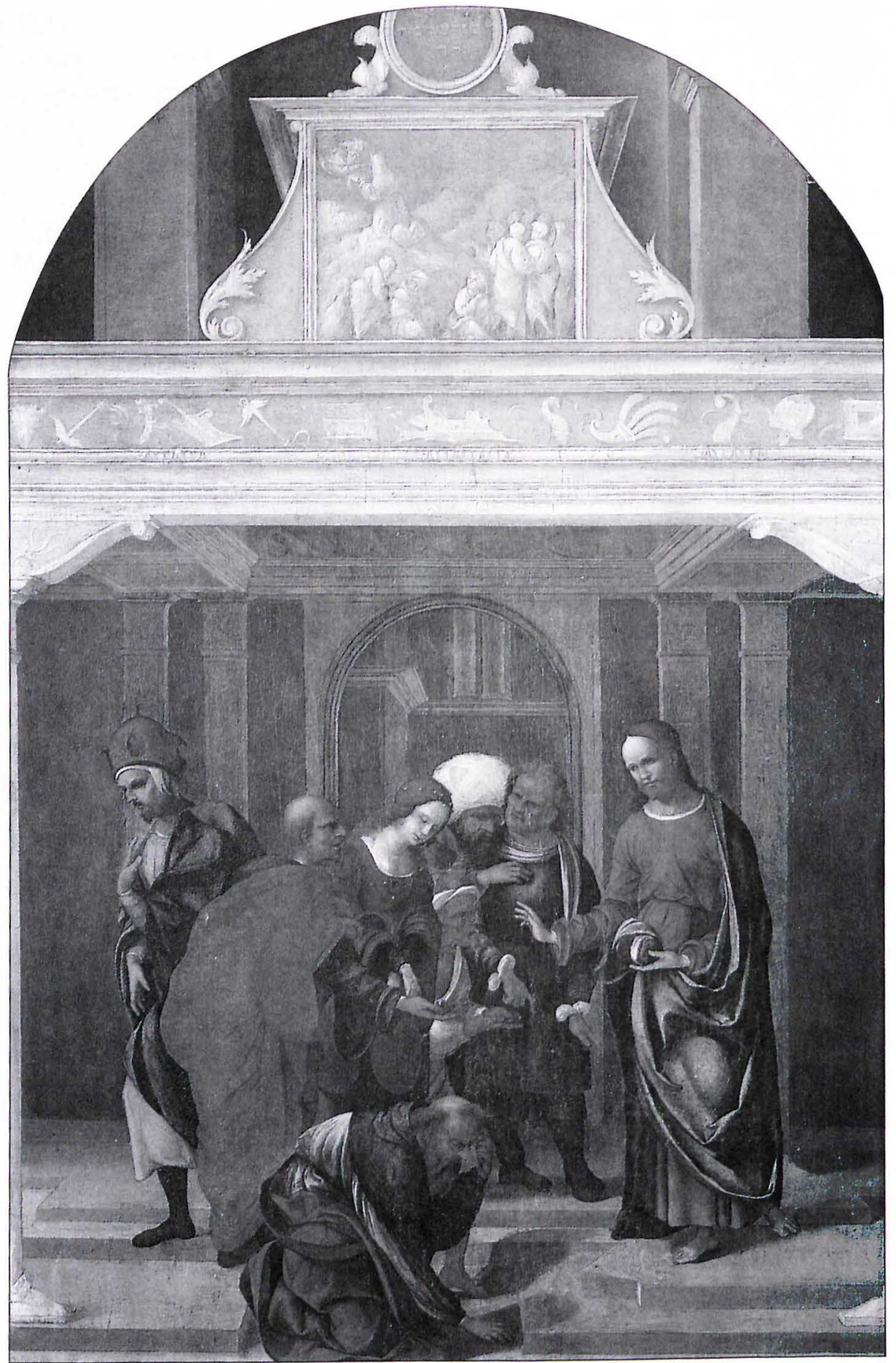

FIGURE 5.5. Ludovico Mazzolino, Christ and the Adulterous Woman, ca. 1519, oil on wood, Florence, Galleria Palatina, Palazzo Pitti.

Erich Lessing / Art Resource, NY. 
In 1556 Pierio Valeriano (1477-ca. 1560) published his Hieroglyphica, a text that represented at that time the sum of knowledge on hieroglyphs and Egyptian culture. The Hieroglyphica claims that Christ and his apostles, following in the footsteps of Moses, David, and the prophets, used a hieroglyphic method in veiling the primordial mysteries and sacred truths of their words through parables and other forms of figurative speech. ${ }^{48}$ Valeriano's appreciation of Christ's hieroglyphic method adds another layer of meaning to interpreting Mazzolino's Christ and the Adulterous Woman. The composition shows Christ disputing with the scribes and Pharisees over the fate of a woman caught committing adultery. According to the Gospel of John (8:3-11), the Pharisees, in their attempt to trap Jesus in a legal conundrum, believing him to be a false Messiah, appeal to Mosaic law, which prescribes stoning any woman who has committed adultery. Appropriately enough, Mazzolino depicts a scene in monochrome of Moses receiving the Ten Commandments. The gospel relates that Jesus scrawled undisclosed words on ground with his finger, and one sees in the painting a scribe bending down and straining to read those words in the shadows. When the Pharisees continued to question him, Jesus replied, "He that is without sin among you, let him first cast a stone at her" (John 8:7). Christ's retort caused the elders to disperse, and the woman's life was spared. In Mazzolino's painting, Christ's posture conveys superiority, whereas the Pharisee kneels down to read Christ's writing as if in supplication. ${ }^{49}$ At left, one elder walks away, visibly stupefied. While the message is one of tolerance and Christian mercy, the artist presents the subject in such a way that Christ's words are fundamentally civil and humane. The painting contrasts the Pharisees, whose strict adherence to ancient law can only reach a fatal conclusion, with Christ, whose response avoids proof in favor of moral and ethical reasoning.

The hieroglyphs on the temple are adapted from a famous and often-copied series of antique reliefs that once adorned the early Christian church of S. Lorenzo fuori le Muri in Rome. These same naval symbols also served as the basis for the fictive relief in Sebastiano del Piombo's emblematic portrait of Andrea Doria, the great naval admiral, of 1526 (Galleria Doria Pamphilj, Rome). ${ }^{50}$ Like the hieroglyphs in the portrait, which both conceal and reveal the inner character of Andrea Doria, the hieroglyphic frieze in Mazzolino's Christ and the Adulterous Woman veils the deeper spiritual message of Christ's words. Conventional aids, such as the eyeglasses or literary compendia used by the scribes in this and in other paintings by Mazzolino, fail to unravel the primordial truths underlying his teachings. This reading is reinforced by the Hebrew inscription in the roundel, which again reads, "The House which Solomon built for the Lord." As in his other paintings, this citation is paired with a monochrome scene of Moses receiving the Ten Commandments, highlighting the role of the Hebrews as protectors and bearers of God's law. Mazzolino enables the viewer to follow how the sacred mysteries and divine laws encoded in the ancient symbols of the

48. Valeriano, Hieroglyphica, fols. 3v-4r; quoted by Galis, "Concealed Wisdom," $365 \mathrm{n} 10$ : "Sed ne in conquirendis multis laborare videar, cum hac hieroglyphica instituendi ratione similitudinem habere comperio divinas nostrorum literas, ita omnia mystico quodam sensu scripta quaecunque Moses, quae David, quae Prophetae reliqui coelesti spiritu afflati protulerunt. In nova vero lege novoque instrumento cum Assertor noster ait, Aperiam in parabolis os meum, et in aenigmate antiqua loquar, quid aliud sibi voluit, quam, hieroglyphice sermonem faciam, et allegorice vetusta rerum proferam monumenta. Et illud, Iesus in Parabolis loquebat ad turbas, nonne sermones suos arcano quasi velamine quodam contegebat. Pari modo videmus Apostolos ab usitato loquendi more recessisse, ut sacra de Deo dicta e ceteris scriptis, sicut merita dignitate, ita et forma quadam discernerentur, ne coelestium mysteriorum maiestas passim et indiscrete patesceret, sanctumque canibus, et margarita porcis exponerent."

49. For an informative reading of Pieter Bruegel's treatment of the same subject, see Kavaler, Pieter Bruegel, 13-20.

50. See Leoncini, "Deduzioni iconografiche"; and Gorse, "Augustan Mediterranean Iconography," with further bibliography. 
Egyptians and in the writings of the Hebrews are subsumed and renewed through the public teachings of Christ, the divine successor to Moses and Solomon. If there is a secret message encoded in the series of hieroglyphs in the Galleria Palatina panel, it would have been up to the artist or humanist adviser to reveal the meaning to the patron. In Filarete's Trattato di Architettura, written in Milan around 1460 to 1464, the ideal prince commissions his architect to devise a monument with an original and covert hieroglyphic inscription, desiring that its cipher be disclosed to him only at a later date. ${ }^{51}$ Ultimately, Mazzolino's courtly patrons could be seen to preserve and perpetuate the dynamic process of spiritual thought through the ownership, display, and discussion of the ancient inscriptions and aenigmata.

Leon Battista Alberti, in a discussion on ornament from his fifteenth-century De Re Aedificatoria $(8: 4)$, suggests that hieroglyphs should replace ordinary letters and conventional inscriptions on monuments, which would otherwise be forgotten and fade into oblivion. Alberti insists that hieroglyphs, just like Greek and Roman narrative relief sculptures honoring famous men, would always be accessible to later generations, but only by "expert men ... to whom alone noble matters should be communicated." ${ }^{22}$ The hieroglyphs that appear on Solomon's temple in Mazzolino's painting therefore provide a symbolic gloss on divine secrecy inherent in the scriptural episode. Christ's words combine universality and exclusivity, sacredness and permanence in their hieroglyphic mode of address, accessible to privileged minds for all eternity. ${ }^{53}$ Following Alberti's lead, it is possible to read the entire imagery of Mazzolino's Christ and the Adulteress Woman as a hieroglyph, connected with the invention of the figurative arts. ${ }^{54}$ It is significant that Calcagnini, who also wrote a translation of the Hieroglyphica of Horapollo sometime between 1505 and 1517, draws parallels between pictorial design and hieroglyphs. ${ }^{55}$ In the dedication letter to his cousin Tommaso, Calcagnini states that his translation was like a preparatory drawing for a large painting, which served as a preview, putting before the viewer's eye the difficulties that needed to be addressed by his intellectual faculties. ${ }^{56}$ Accordingly, with his exuberant display of Hebrew and hieroglyphs, Mazzolino exercises the intuitive and interpretive faculties of his viewers regarding Christ's actions and sayings.

51. "He also wanted an obelisk erected in the middle of these two theaters with the letters that I have mentioned in the forms of animals and other things, almost like the Egyptian ones [quasi come quelle egiziache]. He wanted me to write his name and the date, that is, the year. He said he wanted this done before he understood them, although, as he said, he wanted them explained to him later"; quoted and translated in Curran, Egyptian Renaissance, 85-86. Burroughs, "Hieroglyphs in the Street," 61, 77n29, also cites the relevant example of Bramante's invented hieroglyph for the Vatican Palace, a proposal rejected by Julius II because the rebus was not unique.

52. Alberti, On the Art of Building, 256. See also Burroughs, "Hieroglyphs in the Street," 57-81. Burroughs (60) notes that Paolo Cortesi's De Cardinalatu (ca. 1510) recommends the use of aenigmata and apologi be reserved for the private arenas of a palace.

53. The mystical writings attributed to Dionysius the Aeropagite effectively confirmed for Renaissance humanists and theologians that the sacred scriptures functioned allegorically by preserving "the holy and secret truth" through "unutterable and sacred enigmas"; cited in Curran, Egyptian Renaissance, 74; and see Wind, Pagan Mysteries, 20.

54. Curran, "Hypnerotomachia Poliphili and Renaissance Egyptology," 160, observes that "Alberti appears to place the invention of hieroglyphs at the beginning of the history of the figurative arts, ceding, in the process, the invention of this art to the Egyptians." In addition, Galis, "Concealed Wisdom," interprets Lorenzo Lotto's designs for the intarsia covers in the choir of S. Maria Maggiore, Bergamo (1524) as functionally hieroglyphic.

55. Celio Calcagnini, Opera aliquot, 18-20, reprinted with an Italian translation in Savarese and Gareffi, La letteratura delle immagini nel Cinquecento, 57-68.

56. Calcagnini, Opera aliquot, 18; Savarese and Gareff, La letteratura delle immagini, 60: "Et profecto, qui sunt maiorem quampiam picturam aggressuri, solent eius vestigia, quod ichonographiae beneficium est, praenotare, tum ut aliorum iudicia eliciant, tum ut habeant prae oculis in quibus periclitetur ingenium." 
Mazzolino's use of ancient and arcane paraphernalia also draws attention to the temple as a work of art in and of itself. Mazzolino's highly ornamental style and portrayal of exotic oriental costumes, colors, and inscriptions bypasses Greek and Roman cultures to offer a different kind of antiquity and classicism from that of his contemporary Raphael, to whom he is so often negatively compared. The first book of Kings, chapter 6, describes in great detail Solomon's temple, with its precious materials and elaborate figurative carvings. Mazzolino's imaginative conception of the temple of Jerusalem in his paintings emerges as a palimpsest of King Solomon's divinely inspired artifice. The Hebrew inscription celebrating Solomon's role as architect effectively doubles as a Solomonic identity for the artist. In other words, the Hebrew serves as type of emblematic selfpresentation of artistic wit, ingenuity, and the bizarre so admired by the Ferrarese court. ${ }^{57}$ Notably, Lorenzo Costa (1460-1535), Mazzolino's teacher, signed his Saint Sebastian in Hebrew. ${ }^{58}$ In this way Costa deliberately concealed his identity from the masses and emphatically rewarded the cognoscenti at court by honoring their noble minds. ${ }^{59}$

We can conclude our study by investigating Mazzolino's patronage outside of his native Ferrara, in nearby Bologna. Although documents regarding Mazzolino early career are scarce, he most likely assisted Costa in Bologna, where he retained long-term personal and professional ties. In 1524, Mazzolino painted his Christ Disputing with the Doctors, an extraordinary large-scale work for the physician Francesco Caprara, which was designed for his family chapel in San Francesco in Bologna (now in Gemäldegalerie, Staatliche Museen, Berlin). ${ }^{60}$ This altarpiece, one of his most celebrated works, is filled with Hebrew inscriptions, curious ornaments, and exotically dressed characters. ${ }^{61}$ It is no coincidence that Bolognese humanists, including Filippo Beroaldo the Elder and Giovanni Filoteo Achillini, took a keen interest in the bizarre and the arcane in their own writings. ${ }^{62}$

Caprara was close friends with the Bolognese poet, courtier, and diplomat Girolamo Casio (1464/67-1533) ${ }^{63}$ In 1524, Mazzolino painted a small-scale, private devotional painting representing The Tribute Money (Poznań, Muzeum Narodowe; fig. 5.6) for Casio, and it is this work that merits closer attention. ${ }^{64}$ As an ambassador for the Bolognese state, Casio was on close terms with the courts of Ferrara and Mantua, and the Medici family of Florence bestowed on him many honors, including the privilege of using their last name, and he is sometimes referred to as Girolamo Casio de' Medici. A highly reputed antiquarian, he was also a significant patron of the arts, serving as an artistic broker and writing numerous poems honoring contemporary artists and their works, including those of

57. See the relevant discussion by Campbell, Cosmè Tura, 126-27, as it relates to Ferrarese artists like Mazzolino.

58. Negro and Roio, Lorenzo Costa, 10, 81-82; and Campbell, Cosmè Tura, 26. For Costa's use of Hebrew in his paintings, see further Haitovsky, “New Look at a Lost Painting."

59. See Campbell, Cosmè Tura, 26-27.

60. Zamboni, Ludovico Mazzolino, 36-37; Ballarin, Dosso Dossi, 1:252-53.

61. Lamo, Graticola di Bologna, 80-81, states that while Baldassarre Peruzzi praised this altarpiece as rivaling the works of Raphael on account of its pictorial refinement ("molto diligentisima"), he nonetheless finds its ornament unsightly ("ma con bruto ornamento"). For a translation of the Hebrew inscriptions in this altarpiece, see Haitovsky, "Hebrew Inscriptions," $135-40$.

62. See D’Amico, "Progress of Renaissance Latin Prose."

63. On Casio's life and career, see Fantuzzi, Notizie degli scrittori bolognesi, 3:130-40; Cavicchi, Girolamo Casio; and Berselli, "Un committente e un pittore" (see $127 \mathrm{n} 10$ for the discrepancies of Casio's date of birth).

64. Zamboni, Ludovico Mazzolino, 24, 51; and Ballarin, Dosso Dossi, 1:254. Mazzolino produced several versions of this subject, another elegant example being housed in Christ Church Picture Gallery, Oxford. 


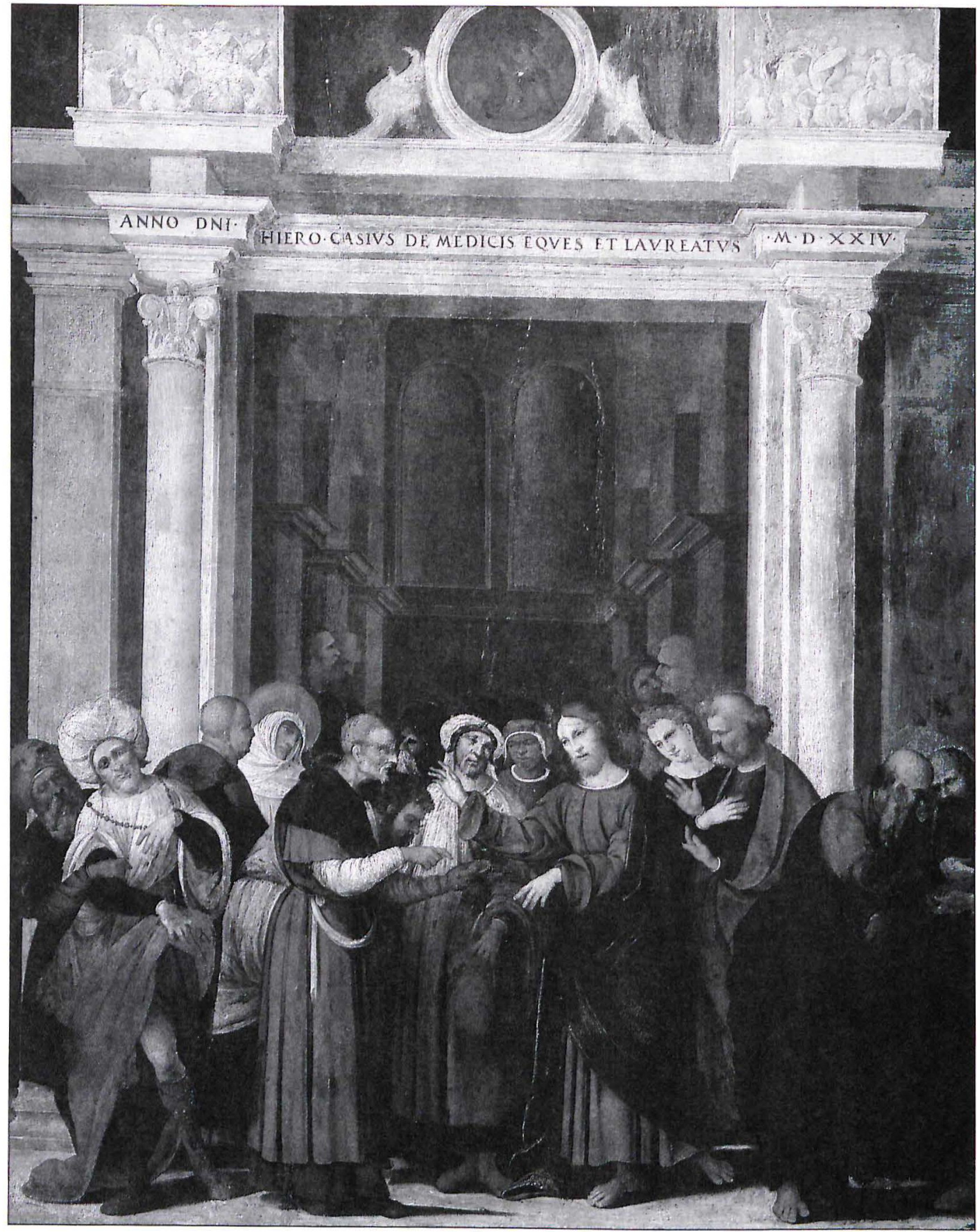

FIGURE 5.6. Ludovico Mazzolino, The Tribute Money, 1524, oil on wood, Poznań, Muzeum Narodowe. Courtesy of Muzium Narodowe, Poznań, Poland. 
Leonardo da Vinci and Francesco Francia. ${ }^{65}$ In 1500, he commissioned from the Milanese artist Giovanni Antonio Boltraffio the famous altarpiece of the Virgin and Child with Donors for his family chapel in Santa Maria della Misericordia in Bologna (now in Musée du Louvre, Paris). ${ }^{66}$

Mazzolino's Tribute Money would have had personal meaning for Casio, who was an avid collector of rare coins and gems. According to the gospels (Matthew 22:15-21, Luke 20:20-26, and Mark 12:13-17), the Pharisees sought Christ in the temple where he was teaching with parables. They plotted to entrap him by tempting him to speak out on the question of whether it was lawful to pay taxes to the emperor. If Jesus approved of paying taxes he would offend the Jews; if he denounced payment he could be reported as disloyal to the empire. Aware of their ploy, Jesus demands to be shown a coin and asks whose image it bears. When they respond that it is Caesar's image, Jesus silences them with a retort: "Render therefore unto Caesar the things which are Caesar's; and unto God the things that are God's" (Matthew 22:21). Hearing this, the Pharisees departed from the temple in amazement. In Mazzolino's painting one Pharisee shows Christ the coin and another inspects it while the crowd reacts in wonder to the divine answer. The Tribute Money privileges Christ's intuition over the religious and political power of the Pharisees and the secular laws of the Romans. His maxim offers a new solution to an age-old problem regarding the power struggle between church and state. By evading potential conflict, Christ's actions would have been highly instructive and useful to the patron's role as courtier and diplomat.

Not only did the subject have personal meaning for Casio, but it also emulates courtly patronage. In Ferrara, Alfonso I d'Este commissioned Titian to paint The Tribute Money (Gemäldegalerie Alte Meister, Staatliche Kunstsammlungen, Dresden) (fig. 5.7), datable to ca. 1516, possibly to adorn one of his camerini that housed his collection of rare coins and medals. ${ }^{67}$ The biblical subject was highly relevant to the duke, who had recently ended his role in bloody and prolonged Cambrai Wars against the pope and the Holy Roman Emperor, losing the important territories of Modena and Reggio to Julius II, but nevertheless retaining the sovereignty of the Ferrarese state. Ferrara was traditionally a papal territory with the Este serving as vicars, with the family owed their investitures to the Holy Roman Emperor. For Alfonso, Titian's Tribute Money could address his delicate political position between the opposing forces of the papacy and the Holy Roman Empire at the conclusion of the Cambrai Wars. ${ }^{68}$ In contrast to Titian's dramatic close-up and psychologically intense image, Mazzolino's painting for Casio extols Christ's rhetorical skills, his confidence and divine conviction in the face of opposition. The scene of the Sacrifice of Isaac in the roundel of Mazzolino's painting also stresses obedience to God and is related to his Philadelphia Christ Washing the Apostles' Feet. Both Titian and Mazzolino adapt a form of humanist theology for their

65. For Casio's writings on art, see Pedretti, Documenti e memorie riguardanti Leonardo da Vinci. Highlights include Casio's poem dedicated to Francesco Francia's Adoration of the Child of 1499, commissioned by Anton Galeazzo Bentivoglio for the high altar of Santa Maria della Misericordia in Bologna, in his Vita de' Santi, 55v; and his poem dedicated to Leonardo's St. Anne cartoon in his Cronica, 126r, a volume which also contains epitaphs on artists, including Francia, Boltraffio, Leonardo, Mantegna, and Raphael $(46 \mathrm{r}-46 \mathrm{v})$.

66. On Casio's patronage of Boltraffio, see Berselli, "Un committente e un pittore," 123-43; and Caprara, "Girolamo Casio e il ritratto a Bologna."

67. Weber, "La collezione di pittore ferrarese," 39.

68. Alfonso's delicate balance of power between pope and emperor is expressed by the inscription on his own double ducat, "Que sunt Deo Dei," which quotes Christ's retort to the Pharisees regarding the payment of taxes (Matthew 22:21; Luke 20:25; and Mark 12:17). On the political currency of Alfonso's coin, see Shepherd, "A Letter Concerning Coins"; and Rosenberg, "Money Talks," 38-39. 


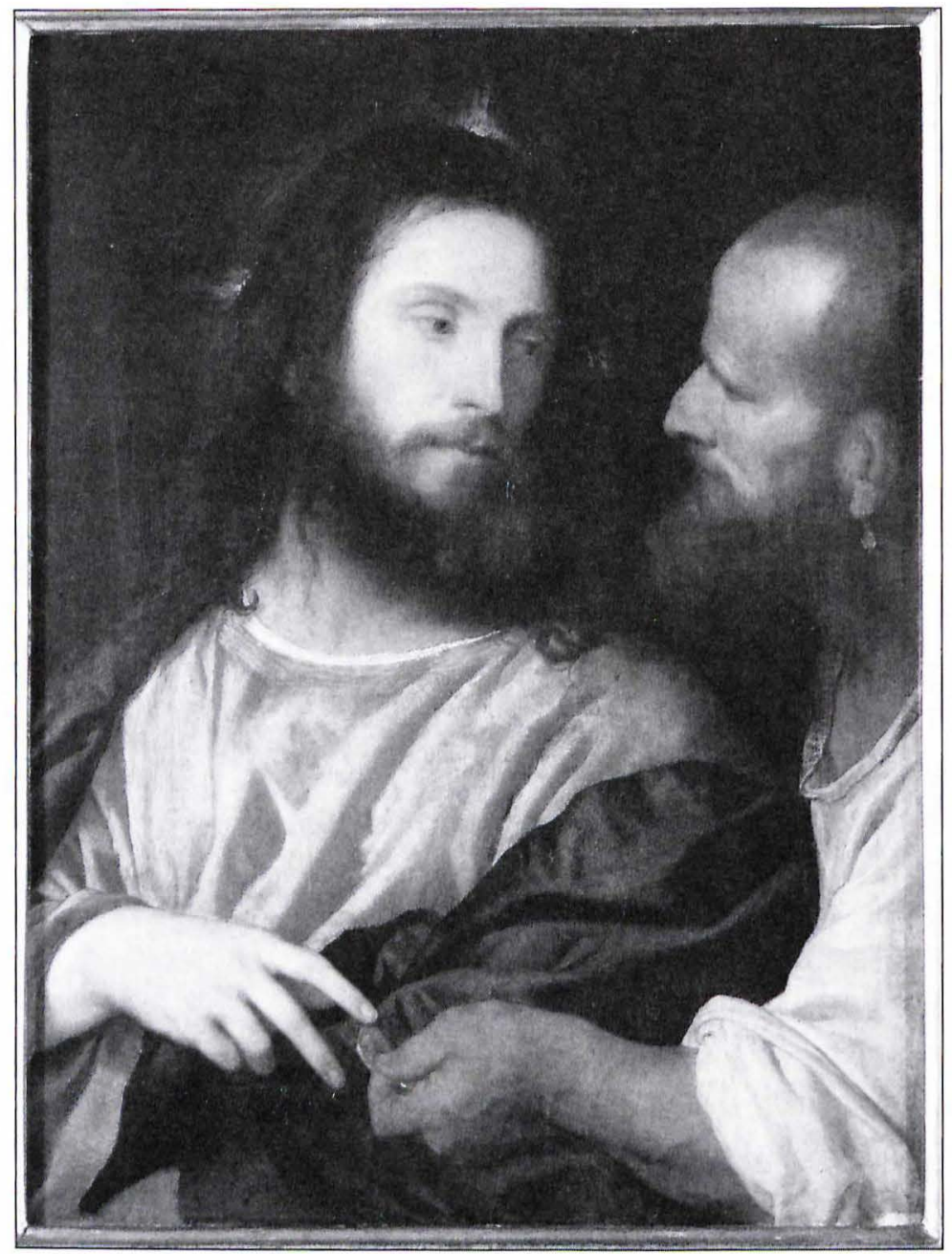

FIGURE 5.7. Titian, The Tribute Money, ca. 1516, oil on wood, Dresden, Gemäldegalerie Alte Meister, Staatliche Kunstsammlungen.

Erich Lessing / Art Resource, NY.

private devotional paintings, which enable their respective patrons to rethink Christ's divine message as a means to overcome various historical or social predicaments.

Casio, who made pilgrimages to the Holy Land and Santiago de Campostela, was deeply religious and wrote extensively on the life of Christ, including a poem focusing on Christ disputing in the temple. ${ }^{69}$ Mazzolino's paintings for his Bolognese patrons complement Casio's vernacular meditational poetry in praise of Christ's actions. Casio dedicated his La Clementina to Clement VII when he ascended to the papal throne in 1523, and the Medici pope crowned Casio poet laureate for his religious verses, which were published in that year. The Latin inscription recorded on 
the entablature in his Tribute Money recognizes Casio as knight and poet laureate, honors and titles awarded to him by the Medici: "ANNO DNI HIERO CASIVS DE MEDICIS EQVES ET LAVREATVS MDXXIV." Instead of a Hebrew citation acknowledging Solomon's construction, the Latin proclaims Casio as the temple's patron. Casio's name appears in the nominative, as if in the title page of a book. In the sixteenth century, the parallel between book and building grew increasingly familiar, testified by the emergence of architectural frontispieces in publications. ${ }^{70}$ Mazzolino transforms the biblical temple into a metaphoric storehouse of Casio's intellectual treasures, suggesting that he has committed to memory Christ's teachings in order to assist his professional role as a prudent diplomat. For Casio, knowledge equals power over the uncertainties of the political climate in Italy, and power comes in the form of divine revelation of sacred mysteries. ${ }^{71}$ Through the contemplation of such a congratulatory image of Christ, the painting was designed to awaken in Casio his poetic and deliberative faculties: to enrich the temple of his mind with the secret treasures of divine wisdom. ${ }^{72}$

\section{Bibliography}

Alberti, Leon Battista. On the Art of Building in Ten Books. Translated by Joseph Rykwert, Neil Leach, and Robert Tavernor. Cambridge, MA: MIT Press, 1988.

Ballarin, Alessandro. Dosso Dossi: La pittura a Ferrara negli anni del ducato di Alfonso I. 2 vols. Cittadella: Bertoncello Artigrafiche, 1994-95.

Baruffaldi, Girolamo. Vita di Lodovico Mazzolino pittore ferrarese. Ferrara: Domenico Taddei, 1843.

Berselli, Elisabetta. "Un committente e un pittore alle soglie del Cinquecento: Girolamo Casio e Giovanni Antonio Boltraffio." Schede umanistiche 2 (1997): 123-43.

Bonfil, Robert. "Judeo-Christian Cultural Relations in Cinquecento Ferrara." In Phaethon's Children: The Este Court and Its Culture in Early Modern Studies, edited by Dennis Looney and Deanna Shemek, 301-19. Tempe: Arizona Center for Medieval and Renaissance Studies, 2005.

Borella, Marco. "Lo 'Studio de preda Marmora fina' sopra la via Coperta di Alfonso III duca," In Il camerino d'alabastro: Antonio Lombardo e la scultura all'anitca, edited by Matteo Ceriana, 111-17. Silvana: Milan, 2004.

Borsetti, Ferrante. Historiae almi ferrariae gymnasia. Vol. 2. Ferrara: Bernardini Pomatelli, 1735.

Burroughs, Charles. "Hieroglyphs in the Street: Architectural Emblematics and the Idea of the Façade in Early Sixteenth-Century Palace Design." In The Emblem and Architecture: Studies in Applied Emblematics from the Sixteenth to the Eighteenth Centuries, edited by Hans J. Böker and Peter M. Daly, 57-82. Turnhout: Brepols, 1999.

Busi, Giulio. L'Enigma dell'ebraico nel Rinascimento. Turin: Aragno, 2007.

Calcagnini, Celio. Descriptio Silentii. In Opera aliquot, 491-94. Basel: Froben, 1544.

Opera aliquot. Basel: Froben, 1544.

Camerino di alabastro: Antonio Lombardo e la scultura all'antica. Edited by Matteo Ceriana. Milan: Silvana, 2004.

Campbell, C. Jean. "Pier Maria Rossi's Treasure: Love, Knowledge and the Invention of the Source in the Camera d'Oro at Torrechiara." In Emilia e Marche nel Rinascimento: L'identità visiva della "Periferia," edited by Giancarla Periti, 63-88. Azzano San Paolo: Bolis, 2005.

70. Burroughs, “Hieroglyphs in the Street," 59.

71. See Lochrie, Covert Operations, 99.

72. See Campbell, "Pier Maria Rossi's Treasure," 81, who defines Pier Maria Rossi's camera d'oro at Torrechiara, painted with scenes of ritual courtship, as a poetic and transformative space, arguing that "the architectural container of Pier Maria's worldly wealth - a potential prison - is to be gradually discovered in the process of contemplation, as his living body, the repository and seat of real treasures, his God-given poetic faculty and fully realized soul." 
Campbell, Stephen. Cosmè Tura of Ferrara: Style, Politics and the Renaissance City, 1450-1495. New Haven, CT: Yale University Press, 1997.

Camporeale, Salvatore I. "Renaissance Humanism and the Origins of Humanist Theology." In Humanity and Divinity in Renaissance and Reformation: Essays in Honor of Charles Trinkhaus, edited by John W. O'Malley, Thomas M. Izbicki, and Gerald Christianson, 101-24. Leiden: E. J. Brill, 1993.

Caprara, Francesco. “Girolamo Casio e il ritratto a Bologna, fra religione, moda e letteratura.” Il Carrobbio 26 (2000): $61-82$.

Casio, Girolamo. Cronica. Bologna, 1525 [1528].

—.Vita de' Santi. Bologna, 1524.

Cavicchi, Filippo. Girolamo Casio (1464-1533). Turin: Ermanno Loescher, 1915.

Cittadella, Cesare. Catalogo istorico de' pittori e scultori ferraresi. Vol. 1. Ferrara: Francesco Pomatelli, 1782.

Colantuono, Anthony. “Dies Alcyoniae: The Invention of Bellini's Feast of the Gods.” Art Bulletin 73 (1991): 237-56.

Colie, Rosalie. The Resources of Kind: Genre-Theory in the Renaissance. Edited by Barbara Lewalski. Berkeley: University of California Press, 1973.

Curran, Brian. The Egyptian Renaissance: The Afterlife of Ancient Egypt in Early Modern Italy. Chicago: University of Chicago Press, 2007.

. "The Hypnerotomachia Poliphili and Renaissance Egyptology.” Word and Image 14 (1998): 156-85.

D'Amico, John. “The Progress of Renaissance Latin Prose: The Case of Apuleianism.” Renaissance Quarterly 37 (1984): 351-92.

Dempsey, Charles. "Renaissance Hieroglyphic Studies and Gentile Bellini’s Saint Mark Preaching in Alexandria." In Hermeticism and the Renaissance: Intellectual History and the Occult in Early Modern Europe, edited by Indrid Merkel and Allen G. Debus, 342-65. Washington, DC: Folger Books; London and Toronto: Associated Presses, 1988.

Eamon, William. Science and the Secrets of Nature: Books of Secrets in Medieval Modern Culture. Princeton, NJ: Princeton University Press, 1994.

Eco, Umberto. The Search for the Perfect Language. Translated by James Fentress. Oxford, UK: Blackwell, 1997.

Fantuzzi, Giovanni. Notizie degli scrittori bolognesi. Vol. 3. Bologna: San Tommaso D’Aquino, 1783.

Fiorenza, Giancarlo. Dosso Dossi: Paintings of Myth, Magic, and the Antique. University Park: Pennsylvania State University Press, 2008.

Folin, Marco. “Studioli, vie coperte, gallerie: Genealogia di uno spazio del potere." In Il Camerino di alabastro: Antonio Lombardo e la scultura all'antica, edited by Matteo Ceriana, 97-109. Milan: Silvana, 2004.

Franceschini, Adriano. Artisti a Ferrara in età umanistica e rinascimentale: Testimonianze archivistiche. Pt. 2, vol. 2. Ferrara: Corbo, 1997.

Presenza ebraica a Ferrara: Testimonianze archivistiche fino al 1492. Florence: Leo S. Olschki, 2007.

Friedman, Jerome. The Most Ancient Testimony: Sixteenth-Century Christian-Hebraica in the Age of Renaissance Nostalgia. Athens: Ohio University Press, 1983.

Galis, Diana. "Concealed Wisdom: Renaissance Hieroglyphic and Lorenzo Lotto's Bergamo Intarsia.” Art Bulletin 62 (1980): 363-75

Gelli, Giovambattista. La Vita di Alfonso da Este Duca di Ferrara. Venice: Giovanni Battista and Giovanni Bernardo Sessa, 1597.

Giovio, Paolo. Liber de vita et rebus gestis Alfonsi Atestini Ferrariae Principis. Florence: Lorenzo Torrentino, 1551.

Goodgal, Dana. "The Camerino of Alfonso I d'Este." Art History 1 (1978): 162-90.

Gorse, George L. "Augustan Mediterranean Iconography and Renaissance Hieroglyphics at the Court of Clement VII: Sebastiano del Piombo's Portrait of Andrea Doria." In The Pontificate of Clement VII: History, Politics, Culture, edited by Kenneth Gouwens and Sheryl Reiss, 313-37. Burlington, VT: Ashgate, 2005.

Greene, Thomas. "Erasmus's Festina lente: Vulnerabilities of the Humanist Text." In "Mimesis" from Mirror to Method, Augustine to Descartes, edited by John Lyons and Stephen G. Nichols Jr., 132-48. Hanover, NH: University Press of New England, 1982. 
Gundersheimer, Werner. "The Patronage of Ercole I d'Este." Journal of Medieval and Renaissance Studies 6 (1976): 1-18.

Haitovsky, Dalia. “The Hebrew Inscriptions in Ludovico Mazzolino's Paintings." In Jewish Studies at the Turn of the Twentieth Century, edited by Judit Targarona Borrás and Angel Sáenz-Badillos, 133-45. Leiden: Brill, 1999. . "A New Look at a Lost Painting: The Hebrew Inscription in Lorenzo Costa's Presentation in the Temple." Artibus et historiae 15 (1994): 111-20.

Hope, Charles. "I Camerini d'alabastro: A collocazione e la decorazione pittorica." In Il camerino d'alabastro: Antonio Lombardo e la scultura all'antica, edited by Matteo Ceriana, 83-95. Silvana: Milan, 2004.

Horowitz, Elliott. "Jewish Confraternal Piety in Sixteenth-Century Ferrara: Continuity and Change." In The Politics of Ritual Kinship: Confraternities and Social Order in Early Modern Europe, edited by Nicholas Terpstra, 150-71. Cambridge, UK: Cambridge University Press, 2000.

Iversen, Erik. The Myth of Egypt and Its Hieroglyphs in European Tradition. Princeton, NJ: Princeton University Press, 1961. Reprint, 1991.

Katz, Dana E. The Jew in the Art of the Italian Renaissance. Philadelphia: University of Pennsylvania Press, 2008.

Kavaler, Ethan Matt. Pieter Bruegel: Parables of Order and Enterprise. Cambridge, UK: Cambridge University Press, 1999.

Kessler, Herbert. "Medieval Art as Argument." In Iconography at the Crossroads, edited by Brendan Cassidy, 59-73. Princeton, NJ: Trustees of Princeton University, 1993.

Lamo, Pietro. Graticola di Bologna (1560). Edited by Marinella Pigozzi. Bologna: Coopertiva Libraria Universitaria, 1996.

Lazzari, Alfonso. "Un enciclopedico del sec. XVI: Celio Calcagnini." Atti e Memorie della Deputazione Ferrarese di Storia Patria 30 (1936): 83-164.

Leoncini, Luca. "Deduzioni iconografiche, linguaggio geroglifico e uso dell'antico: Il caso del Ritratto Doria." In Il Ritratto e la memoria, edited by Augusto Gentili, Philippe Morel, and Claudia Cieri Via, 249-61. Rome: Bulzoni, 1993.

Liebenwein, Wolfgang. Studiolo: Storia e tipologia di uno spazio culturale, edited by Claudia Ceri Via and translated by Alessandro Califano. Ferrara: Panini, 2005.

Lochrie, Karma. Covert Operations: The Medieval Use of Secrecy. Philadelphia: University of Pennsylvania Press, 1999.

Magnani, Romolo. La ceramica ferrarese tra Medioevo e Rinascimento. 2 vols. Ferrara: Belriguardo, 1981-82.

Manca, Joseph. "Renaissance Theater and Hebraic Ritual in Ercole de' Roberti's Gathering of Manna." Artibus et historiae 9 (1988): $137-47$.

Mann Phillips, Margaret. The Adages of Erasmus: A Study with Translations. Cambridge, UK: Cambridge University Press, 1964.

Negro, Emilio, and Nicosetta Roio. Lorenzo Costa 1460-1535. Modena: Artioli, 2001.

O'Malley, John W. "Content and Rhetorical Forms in Sixteenth-Century Treatises on Preaching." In Religious Culture in the Sixteenth Century: Preaching, Rhetoric, Spirituality, and Reform, 238-52. Aldershot, UK; Brookfield, VT: Variorum, 1993.

. "Egidio da Viterbo and Renaissance Rome." In Religious Culture in the Sixteenth Century: Preaching, Rhetoric, Spirituality, and Reform, 67-84. Aldershot, UK; Brookfield, VT: Variorum, 1993.

- Religious Culture in the Sixteenth Century: Preaching, Rhetoric, Spirituality, and Reform. Aldershot, UK; Brookfield, VT: Variorum, 1993.

O’Rourke Boyle, Marjorie. Erasmus on Language and Method in Theology. Toronto: University of Toronto Press, 1977.

Owen Hughes, Diana. “Distinguishing Signs: Ear-Rings, Jews and Franciscan Rhetoric in the Italian Renaissance City." Past and Present 112 (1986): 3-59.

Pedretti, Carlo, ed. Documenti e memorie riguardanti Leonardo da Vinci a Bologna e in Emilia. Bologna: Fiammenghi, 1953.

Piana, Ernesto. Ricerche ed osservazioni sulla vita e sugli scritti di Celio Calcagnini umanista ferrarese del secolo XVI. Rovigo: A. Conzatti, 1899.

Resnick, Irven. “Lingua dei, lingua hominis: Sacred Language and Medieval Texts." Viator 21 (1990): 51-74.

Rosenberg, Charles. The Este Monuments and Urban Development in Renaissance Ferrara. Cambridge, UK: Cambridge University Press, 1997. 
"Money Talks: Numismatic Propaganda under Alfonso I d'Este." In L'Età di Alfonso I e la pittura del Dosso, 145-64. Modena: Franco Cosimo Panini, 2004.

Rotondo, A. "Pellegrino Prisciani." Rinascimento 9 (1960): 69-110.

Ruderman, David B. "The Founding of a Gemilut Hasadim Society in Ferrara in 1515." Association of Jewish Studies Review 1 (1976): 233-67.

. "The Italian Renaissance and Jewish Thought." In Renaissance Humanism: Foundations, Forms, and Legacy, edited by Albert Rabil Jr., 1:382-433. Philadelphia: University of Pennsylvania Press, 1988.

- The World of a Renaissance Jew: The Life and Thought of Abraham ben Mordecai Farissol. Cincinnati, OH: Hebrew Union Press, 1981.

Savarese, Gennaro, and Andrea Gareffi, ed. La letteratura delle immagini nel Cinquecento. Rome: Bulzoni, 1980.

Schwarzenberg, Erkinger. "Die Lunetten der 'stanza del Tesoro' im Palast des Ludovico il Moro zu Ferrara." Arte Antica e Moderna 26 (1964): 131-50 [Italian translation edited by Giacomo Bargellesi, "Le lunette della Stanza del Tesoro nel Palazzo di Ludovico Il Moro a Ferrara." Atti e Memorie Deputazione Province Ferrarese di Storia Patria 6 (1967): 45-96].

Shepherd, Rupert. "A Letter Concerning Coins in Sixteenth-Century Ferrara." Apollo 149 (1999): 40-43.

Snyder, Jon R. Dissimulation and the Culture of Secrecy in Early Modern Europe. Berkeley: University of California Press, 2009.

Steadman Sheard, Wendy. “Antonio Lombardo's Reliefs for Alfonso d'Este's Studio di Marmi: Their Significance and Impact on Titian." Studies in the History of Art 45 (1993): 315-57.

Tiraboschi, Girolamo. Storia della letturatura italiana. Vol. 7. Modena: La Società Tipografica, 1792.

Trinkhaus, Charles. "The Religious Thought of the Italian Humanists, and the Reformers: Anticipation or Autonomy?" In The Pursuit of Holiness in Late Medieval and Renaissance Religion, 339-66. Leiden: E. J. Brill, 1974.

Valeriano, G. Pierio. Hieroglyphica. Basel, 1556.

Weber, Gregor J. M. “La collezione di pittore ferrarese a Dresda." In Il Trionfo di Bacco: Capolavori della scuola ferrarese a Dresda, edited by Gregor J. M. Weber, 37-48. Turin: Umberto Allemandi, 2002.

Wind, Edgar. Pagan Mysteries in the Renaissance. New York: W. W. Norton and Co., 1958; revised, 1968.

Wittkower, Rudolph. "Hieroglyphics in the Early Renaissance." In Allegory and the Migration of Symbols, 113-28. Boulder: Westview Press, 1977.

Wood, Christopher S. Forgery, Replica, Fiction: Temporalities of German Renaissance Art. Chicago: Chicago University Press, 2008.

Zamboni, Silla. Ludovico Mazzolino. Milan: Silvana, 1968. 